\title{
Efficacy Of Using SOYBEAN MILK-BASED SEMEN EXTENDER For FREEZABILITY OF BUCK SPERMATOZOA
}

\author{
Soltan, W. M*; E. M. El-Siefy ${ }^{\star}$, I. M. Abd El-Razek ${ }^{\star \star}$ and I. S. \\ El-Shamaa** \\ *Biotechnology Res. Dept. Anim. Prod. Res. Insti., Agric. Res., Center, \\ Egypt. ${ }^{*}$ Anim. Prod. Dept. Fac. of Agric., Kafr El-Sheikh Univ. Egypt
}

\begin{abstract}
The aim of this study was to investigate incorporating whole soybean milk instead of the traditional egg yolk in goat semen extender. The semen ejaculates were collected from three fertile bucks, aged 2.0 - 3 years using artificial vagina. Collected semen was divided into 6 parts; the first was diluted with Tris-egg yolk extender (TEY) saved as control, while the others were diluted with Tris- soybean milk extender (TSM) at levels of 5, 10, 15, 20 and $25 \%$. Pooled ejaculates were further processed for freezing using $0.25 \mathrm{ml}$ French straws. Diluted semen at a rate of $1: 4$ was placed into a refrigerator at $5^{\circ} \mathrm{C}$ for $4 \mathrm{~h}$ as equilibration period. At the end of equilibration period, extended semen was packaged in straws and stored at $-196^{\circ} \mathrm{C}$. Then after, frozen semen was thawed by dipping the straws into a water bath at $37^{\circ} \mathrm{C}$ for 30 seconds. Percentages of sperm motility, live spermatozoa, sperm abnormalities and recovery rate were determined.

The results revealed that there were significant differences $(P<0.05)$ in buck sperm characteristics (percentages of sperm motility, live spermatozoa, sperm abnormalities and plasma membrane and acrosome integrity) among post-dilution, post equilibration and post thawing processes. A addition of $15 \%$ of soybean milk led to a significant $(P<0.05)$ improvement of sperm motility, live spermatozoa, sperm abnormalities and plasma membrane and acrosome integrity of buck spermatozoa during different stages of cryopreservation compared to control, while the lowest values were recorded at a level of $25 \%$ soybean milk extender.

On the basis of our results, we concluded that soybean milk-based extender at the rate of $15 \%$ of soybean milk has the potential to maintain buck sperm quality after freezing -thawing process compared with cryopreservation in a traditional protection extender (egg yolk) .
\end{abstract}

\section{INTRODUCTION}

The artificial insemination (AI) in goats is biotechnological method providing augmentation of the genetic merit in goat flocks (Leboeuf et al., 2000). Successful preservation of superior male sperm will give the chance for future recalling even in the absence of those males. Egg yolk is a major constituent of extenders used for storage and cryopreservation of semen of domestic animals including bull, ram, goat and pig. The main advantage of egg yolk extender is 
the fraction of low density lipoprotein which protects the sperm phospholipids during cryopreservation (Amirat et al., 2005). However, wide variations in the constituents of egg yolk make the beneficial effect difficult to assess (Gil et al., 2003; Amirat et al., 2005). Moreover, the fertilizing capacity of spermatozoa is negatively affected by the risk of microbial contamination associated with egg yolk (Bousseau et al., 1998; Aires et al., 2003). It has also been reported that the fat globules of egg yolk makes the evaluation of sperm difficult (Singh et al., 2012). These circumstances demand for the partial or complete replacement of egg yolk with lecithin derived from plant source such as soybeans for the preservation of animal semen. Currently, egg and milk based extenders are extensively used for semen extension and storage of different animal species (Kasimanickam et al., 2011; Khan et al., 2012). Also, vegetable origin extenders are in vogue which is considered to be alternative to milk or yolk based extenders (Gil et al., 2003). According to Aires et al. (2003) soy lecithin-based extender is superior to egg yolk-based extender for bovine and ram semen. In addition El- Keraby et al. (2010) found that replacing whole soy- bean milk for traditional egg yolk increased sperm motility and decreased bacterial count in postthawed bovine semen extender. So the search for non-animal origin, well defined and contamination free medium for the extension of semen is highly desired (Ansari et al., 2013).Singh et al. (2012) observed that $25 \%$ Soya based extender produced better motility, viability, membrane and acrosome integrity of bovine sperm at $5^{\circ} \mathrm{C}$ at different time interval. In Friesian Holstein bulls, Raden and Tuty (2010) observed significant differences in the percentages of post thawed sperm motility in semen preserved with Tris-egg yolk (TEY) $49.1 \%$, Andromed $50.21 \%$ or Tris soybean milk (TSM) $41.53 \%$. While, the conception rates of the cows inseminated with frozen thawed semen containing TSM, TEY and Andromed were 53.84, 38.88 and $38.46 \%$, respectively. In buffalo bulls, E-Keraby et al. (2013) recoded a significant increase in the post-thaw sperm motility in frozen semen diluted with $10 \%$ soybean milk (SBM) compared with frozen semen diluted with $20 \%$ egg yolk extender (EY), the conception rates in buffalo cows inseminated with frozen thawed semen containing $10 \%$ SBM and EY were 66.1 and 54\%, respectively. In Holstein bulls, ElSiefy, (2014) recoded a significant increase in post-thaw progressive motility, viability, plasma membrane and acrosome integrity in frozen semen diluted with 7\% soybean milk (SBM) compared with frozen semen diluted with $20 \%$ egg yolk extender (EY), the high fertility rate was recorded in cows inseminated with frozen thawed semen containing 7\% SBM and EY were 68.3 and $61.8 \%$, respectively. Therefore, the present study was planned to investigate the impact of 
using different concentrations of whole soybean milk instead of traditional egg yolk on cryopreservation of frozen buck spermatozoa.

\section{MATERIALS AND METHODS}

\section{Experimental Animals}

The present study was conducted at El- Karada Experimental Farm belonging to Animal Production Research Institute (APRI), Ministry of Agriculture, Egypt. Three sexually mature Baladi bucks male aged $2.0-3$ years and weighed 60 kilogram in average were used in the current study for eight months (December 2015 to July 2016). All bucks were healthy and clinically free of internal and external parasites. The animals were kept under natural photoperiod and balanced nutritional status. The rations offered to bucks adjusted to meet there requirements during breeding season according to NRC (2007). Fresh water was available during the experimental period.

\section{Preparation of soybean milk}

The soybean milk was prepared according to the method described by El-Keraby et al. (2010). Briefly, a total of 10 grams of soybean grains was washed, soaked in $100 \mathrm{ml}$ distilled water and boiled for $30 \mathrm{~min}$. After boiling, the water was discarded, the whole soybean grains washed again and finally cooled down with $50 \mathrm{ml}$ distilled water containing $0.25 \% \mathrm{NaHCo}$. The soybean grains were then grounded in a blender for $5 \mathrm{~min}$ and the slurry cooled. Soybean milk was extracted by filtration through a clean cotton cloth, centrifuged and boiled again for 10 minutes. The slurry was allowed again to cool down. Then, antibiotics were added at the rate of $0.25 \mathrm{~g}$ Lincospectin and $0.005 \mathrm{~g}$ Streptomycin $/ 100 \mathrm{ml}$ of the slurry. After that, the SBM extender was ready for use.

\section{Semen evaluation}

Following sexual preparation, semen was collected twice weekly by artificial vagina from three bucks for eight months (December 2015 to July 2016). Palpation of the external genitalia showed that they were typically normal. The testicular tone was glandular, almost equal in size and moved freely up and down within the scrotal pouches.

Immediately after semen collection, ejaculates were held in a water bath at $37 \mathrm{C}$ until evaluated. Ejaculates having good mass motility (more than $75 \%$ ) were used and pooled. On each collection day, semen was divided into 6 parts; the first was diluted with Tris-egg yolk extender (control), while the others were diluted with Tris-soy milk extender at levels of $5,10,15,20$ and $25 \%$ soybean milk. 
Tris-egg yolk extender consisted of $3.07 \mathrm{~g}$ Tris (hydroxymethyl amino methane), $1.64 \mathrm{~g}$ citric acid, $1.26 \mathrm{~g}$ fructose, $15 \mathrm{ml}$ egg yolk, $5 \mathrm{ml}$ glycerol, $0.05 \mathrm{~g}$ streptomycin, $0.25 \mathrm{~g}$ lincospectin and completed with bi-distilled water up to $100 \mathrm{ml}$.(control). While, Tris- soybean milk extender consisted of $3.07 \mathrm{~g}$ Tris, $1.64 \mathrm{~g}$ citric acid, $1.26 \mathrm{~g}$ fructose, 5,7 , 10,15 or $20 \mathrm{ml}$ soybean milk, $5 \mathrm{ml}$ glycerol, $0.05 \mathrm{~g}$ streptomycin, $0.25 \mathrm{~g}$ lincospectin and completed with bi-distilled water up to $100 \mathrm{ml}$.

\section{Semen processing}

Good ejaculates were further processed for freezing using $0.25 \mathrm{ml}$ French straws containing about $100 \times 10^{6}$ motile sperm before freezing. The dilution rate was 1:4. The Tris-egg yolk and Trissoybean milk extenders were gently mixed and warmed up to $37^{\circ} \mathrm{C}$ in a water bath during semen extension. Vials containing the extended semen were placed in a water bath at $37^{\circ} \mathrm{C}$ and cooled gradually in a refrigerator at $5^{\circ} \mathrm{C}$ for 4 hours as an equilibration period. .

At the end of equilibration period, the extended semen was loaded in $0.25 \mathrm{ml}$ French straws. During packaging in straws, extended semen was kept in an ice water bath at $5^{\circ} \mathrm{C}$. Straws were transferred into a processing canister and located horizontally in static nitrogen vapor 4 $\mathrm{cm}$ above the surface of liquid nitrogen for 10 minutes. The straws were then placed vertically in a metal canister and immersed completely in liquid nitrogen container for storage at $-196^{\circ} \mathrm{C}$. Freezing process was recorded as the method described by Salisbury et al. (1978). For thawing, straws were dipped into a water bath at $37^{\circ} \mathrm{C}$ for 30 seconds.

The sperm progressive motility was determined according to Melrose and Laing, (1970), live and abnormal spermatozoa were evaluated using eosin negrosin mixture prepared as described by Hancock, (1951), plasma membrane integrity of spermatozoa was according to Jeyendran et al., (1984) and acrosome integrity was assessed using Geimsa stain according to Watson (1975) in post-diluted, postequilibrated and post-thawed semen.

\section{Statistical analysis}

Data were statistically analyzed using a statistical software (SPSS, version 18.0). One-way analysis of variance was used to test the significance of extenders on the studied traits (Steel et al., 1997). Means of the significantly affected traits were separated by Duncan Multiple Range Test (Duncan, 1955).

Sperm progressive motility (\%):

\section{RESULTS}

The effect of different levels of soybean milk addition on progressive sperm motility after dilution, equilibration and post-thawing 
were presented in Table(1). Sperm motility percentages were significantly $(\mathrm{P}<0.05)$ improved by 15 and $20 \%$ soybean milk extenders while high and low levels of soybean extenders decreased progressive motility compared to control. The superior percentages of sperm motility after dilution, equilibration and freeze-thawing processes were recorded in semen extended with $15 \%$ soybean milk extender. The lowest sperm motility were recorded in extenders containing 5, 10 and $25 \%$ soybean milk compared to Tris egg yolk extender.

Table (1): Effect of different soybean milk concentrations on progressive motility (\%) of buck spermatozoa during different stages of cryopreservation (Mean \pm S.E)

\begin{tabular}{|c|c|c|c|c|c|c|}
\hline \multirow{2}{*}{ Stages } & Control & 5 & 10 & 15 & 20 & 25 \\
\hline & & 5 & \multicolumn{5}{|c|}{ Soybean milk concentrations \% } \\
\hline Post-dilution & $66.2^{\mathrm{b}} \pm 0.66$ & $58.6^{\mathrm{c}} \pm 1.20$ & $66.0^{\mathrm{b}} \pm 0.81$ & $69.7^{\mathrm{a}} \pm 0.76$ & $67.7^{\mathrm{ab}} \pm 0.99$ & $55.2^{\mathrm{d}} \pm 1.16$ \\
\hline $\begin{array}{c}\text { Post-equilibration } \\
\text { (at 5 } \mathrm{o} \text { ) }\end{array}$ & $49.8^{\mathrm{b}} \pm 1.01$ & $39.5^{\mathrm{c}} \pm 1.53$ & $50.2^{\mathrm{b}} \pm 1.25$ & $54.8^{\mathrm{a}} \pm 1.14$ & $51.7^{\mathrm{ab}} \pm 1.35$ & $37.9^{\mathrm{c}} \pm 1.84$ \\
\hline $\begin{array}{c}\text { Post-thawing } \\
27.4^{\mathrm{bc}} \pm \\
1.08\end{array}$ & $11.6^{\mathrm{d}} \pm 0.62$ & $25.4^{\mathrm{c}} \pm 1.08$ & $32.6^{\mathrm{a}} \pm 1.29$ & $30.0^{\mathrm{ab}} \pm 0.98$ & $12.6^{\mathrm{d}} \pm 1.18$ \\
\hline
\end{tabular}

a, b, c and d: the different superscripts in the same row are significant at level $5 \%$.

\section{Live sperm (\%):}

The results in Table (2) indicated that after dilution, after equilibration and post-thawing processes there are a significant affect $(P<0.05)$ on live sperm percentage. The highest live sperm percentage was obtained when semen was extended with $15 \%$ soybean milk, while the levels of 5, 10 and $25 \%$ soybean milk extenders showed the lowest live sperm percentage compared to control. The results indicated that live sperm percentages were improved up to $20 \%$ level of soybean milk (Table 2).

Table (2): Effect of different soyabean milk concentrations on live sperm (\%) of buck spermatozoa during different stages of cryopreservation (Mean \pm S.E)

\begin{tabular}{|c|c|c|c|c|c|c|}
\hline \multirow{2}{*}{ Stages } & \multirow{2}{*}{ Control } & \multicolumn{5}{|c|}{ Soya bean concentration $\%$} \\
\hline & & 5 & 10 & 15 & 20 & 25 \\
\hline Post-dilution & $74.6^{b} \pm 0.72$ & $66.5^{\mathrm{C}} \pm 1.10$ & $72.96^{\mathrm{b}} \pm 0.70$ & $77.7^{\mathrm{a}} \pm 0.66$ & $74.4^{\mathrm{b}} \pm 0.76$ & $63.6^{d} \pm 1.03$ \\
\hline $\begin{array}{l}\text { Post-equilibration } \\
\text { (at } 5 \stackrel{\circ}{\circ} \text { ) }\end{array}$ & $59.8^{b} \pm 1.21$ & $47.5^{\mathrm{C}} \pm 1.03$ & $59.1^{b} \pm 1.44$ & $63.5^{\mathrm{a}} \pm 1.19$ & $59.7^{b} \pm 1.33$ & $44.7^{c} \pm 1.48$ \\
\hline Post-thawing & $38.5^{\mathrm{b}} \pm 1.38$ & $18.3^{c} \pm 1.20$ & $34.8^{\mathrm{b}} \pm 1.43$ & $44.3^{\mathrm{a}} \pm 1.69$ & $38.8^{b} \pm 1.14$ & $18.8^{\mathrm{C}} \pm 1.43$ \\
\hline
\end{tabular}

a, b, c and d: the different superscripts in the same row are significant at level $5 \%$. 


\section{Sperm abnormalities (\%):}

Sperm abnormalities after different stages of cryopreservation were significantly $(\mathrm{P}<0.05)$ lower in semen extended with $15 \%$ soybean milk as compared to control and other levels of soybean milk extenders (Table 3 ).

Table (3): Effect of different soy bean milk concentrations on abnormal sperm (\%) of buck spermatozoa during different stages of cryopreservation (Mean \pm S.E)

\begin{tabular}{|c|c|c|c|c|c|c|}
\hline \multirow{2}{*}{ Stages } & \multirow{2}{*}{ Control } & \multicolumn{5}{|c|}{ Soya bean concentration $\%$} \\
\hline & & 5 & 10 & 15 & 20 & 25 \\
\hline Post-dilution & $7.5^{\mathrm{bc}} \pm 0.11$ & $8.2^{\mathrm{ab}} \pm 0.19$ & $7.5^{\mathrm{bc}} \pm 022$ & $7.2^{c} \pm 0.21$ & $8.0^{\mathrm{ab}} \pm 0.74$ & $8.5^{a} \pm 0.38$ \\
\hline $\begin{array}{c}\text { Post-equilibration } \\
\text { (at } 5 \stackrel{\circ}{\circ} \text { ) }\end{array}$ & $8.4^{\mathrm{ab}} \pm 0.19$ & $8.9^{a} \pm 0.25$ & $7.9^{b} \pm 0.21$ & $7.8^{b} \pm 0.28$ & $8.2^{\mathrm{ab}} \pm 0.26$ & $8.9^{a} \pm 0.45$ \\
\hline Post-thawing & $8.9^{b c} \pm 0.20$ & $9.7^{\mathrm{ab}} \pm 0.28$ & $8.9^{b c} \pm 0.25$ & $8.2^{c} \pm 0.26$ & $8.9^{b c} \pm 0.32$ & $\begin{array}{c}10.6^{\mathrm{a}} \pm \\
0.54\end{array}$ \\
\hline
\end{tabular}

a, b and $c$ : the different superscripts in the same row are significant at level $5 \%$.

\section{Acrosome integrity (\%):}

After dilution, Post equilibration and post frozen thawed processes the percentages

of buck acrosome integrity in $10 \%, 15 \%$ and $20 \%$ soybean extenders were higher than acrosome integrity in control extender, but the low and high ( 5 and $25 \%$ ) levels of soy bean extenders were significantly $(\mathrm{P}<0.05)$ lower than control and other soybean extenders (Table 4).

Table (4): Effect of different soya bean milk concentrations on Intact acrosome (\%) of buck spermatozoa during different stages of cryopreservation

\begin{tabular}{|c|c|c|c|c|c|c|}
\hline \multirow{2}{*}{ Stages } & Control & 5 & 10 & 15 & 20 & 25 \\
\hline & & 5 & \multicolumn{5}{|c|}{ Soya bean concentrations\% } \\
\hline Post-dilution & $83.9^{\mathrm{a}} \pm 1.03$ & $77.0^{\mathrm{b}} \pm 1.54$ & $84.9^{\mathrm{a}} \pm 0.72$ & $85.9^{\mathrm{a}} \pm 0.08$ & $85.0^{\mathrm{a}} \pm 0.66$ & $77.0^{\mathrm{b}} \pm 1.41$ \\
\hline $\begin{array}{c}\text { Post-equilibration } \\
\text { (at 5 } \mathrm{o} \text { ) }\end{array}$ & $74.6^{\mathrm{a}} \pm 1.22$ & $67.8^{\mathrm{b}} \pm 1.88$ & $77.0^{\mathrm{a}} \pm 1.06$ & $76.3^{\mathrm{a}} \pm 0.91$ & $76.3^{\mathrm{a}} \pm 0.96$ & $66.3^{\mathrm{b}} \pm 1.67$ \\
\hline Post-thawing & $62.1^{\mathrm{b}} \pm 1.45$ & $48.8^{\mathrm{c}} \pm 2.21$ & $65.1^{\mathrm{ab}} \pm 1.33$ & $67.6^{\mathrm{a}} \pm 0.99$ & $65.5^{\mathrm{ab}} \pm 1.16$ & $46.2^{\mathrm{c}} \pm 2.46$ \\
\hline
\end{tabular}

a, b and c : the different superscripts in the same row are significant at level $5 \%$.

\section{Plasma membrane integrity (\%):}

There were significant differences among different extenders on plasma membrane integrity. After dilution, the best plasma 
membrane integrity percentages were recorded in $15 \%$ soybean followed by $20 \%$ and $10 \%$ soybean extenders, while this membrane integrity was lower in high and low $(25 \%$ and $5 \%$ ) soy bean extender when compared to control (table 5). After equilibration process the percentage of plasma integrity was higher in all soybean extender compared to the control, but differences were only significant among $10 \%, 15 \%$ and $20 \%$ soybean extenders and the other soybean extenders and control. After freezing - thawing process the percentage of plasma integrity is significantly $(\mathrm{P}<0.05)$ higher in $15 \%$ soybean extender followed by $10 \%$ and $20 \%$ soybean extenders, while lowest value was recorded in $5 \%$ soybean extenders (table 5 ).

Table (5): Effect of different soybean milk concentrations on plasma membrane integrity (\%) of buck spermatozoa during different stages of cryopreservation (Mean \pm S.E)

\begin{tabular}{|c|c|c|c|c|c|c|}
\hline \multirow{2}{*}{ Stages } & \multirow{2}{*}{ Control } & \multicolumn{5}{|c|}{ Soya bean concentration $\%$} \\
\hline & & 5 & 10 & 15 & 20 & 25 \\
\hline Post-dilution & $73.9^{b} \pm 0.88$ & $68.9^{c} \pm 1.19$ & $76.0^{\mathrm{ab}} \pm 0.74$ & $78.0^{\mathrm{a}} \pm 0.81$ & $76.8^{\mathrm{ab}} \pm 0.99$ & $68.7^{c} \pm 1.42$ \\
\hline $\begin{array}{l}\text { Post-equilibration } \\
\text { (at } 5 \stackrel{\circ}{\circ} \text { ) }\end{array}$ & $65.0^{\mathrm{a}} \pm 1.17$ & $58.0^{b} \pm 2.00$ & $65.8^{\mathrm{a}} \pm 1.48$ & $69.0^{\mathrm{a}} \pm 1.04$ & $66.2^{\mathrm{a}} \pm 1.52$ & $57.0^{b} \pm 2.03$ \\
\hline Post-thawing & $54.7^{\mathrm{a}} \pm 1.53$ & $42.8^{b} \pm 2.84$ & $55.6^{\mathrm{a}} \pm 1.63$ & $58.9^{\mathrm{a}} \pm 1.45$ & $55.5^{\mathrm{a}} \pm 1.37$ & $36.7^{c} \pm 2.97$ \\
\hline
\end{tabular}

$a, b$ and $c:$ the different superscripts in the same row are significant at level $5 \%$.

\section{DISCUSSION}

Egg yolk is reported to have cryoprotectant antagonists, inconsistent composition, high-density lipoproteins (HDLs) and egg yolk granules that interfere with sperm motility (Ansari et al. , 2010). Also, bacteriological property (Bousseau et al. , 1998) and variable nature of egg yolk (Moussa et al. , 2002) are not desirable. Egg yolk is routinely used as a non-permeable cryoprotectant for tris-based extenders, which provide protection against thermal shock and preserve sperm motility, and maintains acrosomal as well as mitochondrial integrity (Moustacas et al. , 2011). Although egg yolk has cryoprotectant abilities, the deterrents associated with its use in semen extenders are of particular concern in present epoch. The component of egg yolk, which gives protection to sperm membrane (phospholipids) integrity during cryopreservation, is the low-density lipoproteins (LDLs) known as lecithin (Moussa et al. , 2002, Amirat et al. , 2004, Andrabi et al. , 2008 and El-Shearawy et al. , 2012).

Soybean contains large proportion of low-density lipoproteins called soya lecithin similar to egg yolk lecithin indicating its membrane 
protecting potential. This was evident after storage of bull semen after thawing of frozen semen which demonstrated that replacement of egg yolk with soya milk-based extender does not show any significant decline in semen characteristics but increase all evaluated parameters. Also, finish product of soya milk is autoclavable hence contain low risk of contamination. In this study, the quality of frozen buck semen preserved with TSM (Tris- soybean milk) diluents was superior to that preserved with TEY (Tris-egg yolk).

These all postulates may explain the high post-thaw progressive motility of buck spermatozoa in semen diluted with $15 \%$ soybean milk extender compared with whole EY control extender. These results are in agreement with those of El-Keraby et al. 2010. ,El-Siefy, 2014) who observed that the use TSM significantly $(\mathrm{P}<0.05)$ increased the post-thaw sperm motility and pregnancy rate in Holstein bull semen. Also, Rehman et al. (2014) concluded that $25 \%$ soy extender could be used as a substitute of conventional egg yolk-based extender for bull semen stored at $4^{\circ} \mathrm{C}$. In buffalo the level of $10 \%$ TSM significantly $(P<0.01)$ improved the post-thaw sperm motility, live sperm, sperm abnormality and pregnancy rate (El-Keraby et al. , 2013). The beneficial effect of using lecithin base extender has been reported by several authors; (Van Wagtendonk et al. , 2000, Thun et al. , 2002. , Aires et al. , 2003) in bovine, (Bard, 2008. , Akhter et al. , 2012) in Buffalo, (Reed et al. , 2009) in human and (Gilab et al. , 2003) in ram semen. The use of Bioxcell and the Biociphos extenders (soy extract diluents commercial brand; IMV, France) in buffalo bull semen significantly increased the post-thaw sperm motility and the viability index compared to semen extended in the Tris-egg yolk extender(Bard ,2008). The same trend was reported by Gilab et al. (2003) who indicated that the subjective motility evaluation was slightly higher in Bioexcell than that in the milk extender in ram frozen semen. In human semen, no significant differences were observed between before and after cryopreservation in media supplemented with egg yolk or soy lecithin for recovery of sperm motility, sperm cell morphology and maintenance of sperm DNA integrity in vitro (Reed et al. , 2009). Both egg yolk and soybean milk contain phospholipids, which protect spermatozoa during cold shock. Freeze-thawing processes impair the plasma membrane functions of buffalo bull spermatozoa (Anzar et al. 2010; El-Keraby et al. 2013 ). The damage to biomembrane system that mostly occurs during cryopreservation reduced sperm motility and fertilizing ability of frozen-thawed spermatozoa (Ansari et al. , 2010). Post-thaw percentage of sperm with intact plasma membrane was higher in $15 \%$ soybean milk extender compared with control and other levels of TSM. In similar studies on prepared extenders containing 
soya-lecithin, higher plasma membrane integrity of bovine semen was reported in AndroMed (Aires et al. 2003), Biociphos Plus (Gil et al. 2000, Amirat et al. , 2004, 2005) and Bioxcell (Gil et al., 2002. , and Stradaioli et al. 2007) compared with egg yolk-based extenders. However, in buffalo, Bioxcell did not improve plasma membrane integrity of spermatozoa (Akhter et al. 2010). Khalifa et al. (2014) found that soybean lecithin could be able to increase proportions of viable frozen-thawed of ram spermatozoa which reflected positively on fertility rates. In goat, Roof et al. 2011 concluded that a commercially available soy-based extender was superior to an egg yolk-based extender in preserving motility of cryopreserved goat sperm, using a two step method, also, the extender containing soybean lecithin and low glycerol provided the best motility and viability of chilled-stored spermatozoa and preserved their fertilization capacity (Yotov 2015).

In the present study, the post-thaw sperm viability was superior in $15 \%$ soybean milk extender compared with control or other TSM extenders. It is noteworthy to mention that HDLs of egg yolk interact with bovine seminal plasma proteins and accelerate the sperm capacitation, while the LDLs interact with seminal plasma proteins (Manjunath et al. 2002), decrease the efflux of cholesterol and phospholipids from the spermatozoa membrane and prevent premature capacitation and subsequent acrosome reaction (Bergeron et al. , 2004). It is to believe that HDLs in egg yolk are responsible for capacitation and simultaneous acrosome reaction (Anton et al. 2003).

Amirat et al. (2005) also recoded the highest sperm numbers with functionally intact acrosomes cryopreserved in soya-lecithinbased extender like Biociphos Plus as compared to an egg yolk-based extender like Triladyl. Bioxcell is the only soya-lecithin-based extender evaluated for freezability and fertility of buffalo bull semen and found similar to tris-citric acid egg yolk extender in fertility rate (Akhter et al. , 2010). It is concluded that $15 \%$ soybean milk-based extender is suitable alternative to egg yolk-based extender for cryopreservation of buck semen and improves semen freezability.

\section{REFERENCES}

Aires, V.A.; K.D. Hinsch; F. Müller-Schlösser; K. Bogner; S. MüllerSchlösser and E. Hinsch (2003). In vitro and in vivo comparison of egg yolk-based and soybean lecithin-based extenders for cryopreservation of bovine semen. Theriogenology., 60: 269-279.

Akhter, S.; M. S. Ansari; B. A. Rakha; S. M. H. Andrab; S. lqbal and N. Ullah (2010). Cryopreservation of buffalo (Bubalus bubalis) semen in Bioxcell extender. Theriogenology., 74: 951-955. 
Akhter, S.; M. S. Ansari; S. M. H. Andrab; B. A. Rakha; N. Ullah and M. Khalid (2012). Soya-lecithin in extender improves the freezability and fertility of buffalo (Bubalus bubalis) bull spermatozoa. Reprod Dom. Anim., 47: 815-819.

Amirat, L.; D. Tainturier; L. Jeannaau; C. Thorin; O. Gerard; J. L. Counters and M. Anton (2004). Bull semen in vitro fertility after cryopreservation using egg yolk LDL: a comparison with Optidyl, a commercial egg yolk extender. Theriogenology., 61: 895-907.

Amirat, L.; M. Anton; D. Tainturier, G. R. Chatagnon; I. Battut and J. L. Courtens (2005). Modifications of bull spermatozoa induced by three extenders: biociphos, low density lipoprotein and Triladyl, before, during and after freezing and thawing. Reprod., 129: 535-543.

Andrabi, S. M. H.; M. S. Ansari, N. Ullah; M. Anwar; A. Mehmood and S. Akhter (2008). Duck egg yolk in extender improves the freezability of buffalo bull spermatozoa. Anim. Reprod. Sci., 104: 427-433.

Ansari, M. S.; B. A. Rakha; S. M. H. Andrabi and S. Akhter (2010). Usefulness of powdered and fresh egg yolk for cryopreservation of Zebu bull spermatozoa. Reprod. Biol., 10: 235-240.

Ansari, M. S.; B. A. Rakha,; N. Ullah; S. M. H. Andrabi, and S. Akhter, (2013). Glutathione addition in Tris-citric egg yolk extender improves the quality of cooled buffalo (Bubalus bubalus) bull semen. Pakistan J. Zool., 43: 49-55.

Anton, M.; V. Martinet; M. Dalgalarrodo; V. Beaumal; E. David-Briand and H. Rabesona (2003). Chemical and structural characterization of low-density lipoproteins purified from hen egg yolk. Food Chem., 83: 175-183.

Anzar, M.; Z. Rasul; T. A. Ahmed and N. Ahmad (2010). Response of buffalo spermatozoa to low temperatures during cryopreservation. Reprod. Fertil. Dev., 22: 871-880.

Bard, M.R. (2008). Cryopreservation of Buffalo spermatozoa in soy lecithin based extender. Assiut Vet. Med. J., 54: 272-284.

Bergeron, A.; M. H. Crete and P. Manjunath (2004). Low-density lipoproteins fraction from hen's egg yolk decreases the binding of the major proteins of bovine seminal plasma to sperm and prevents lipid effux from the sperm membrane. Biol. Reprod., 70: 708-717.

Bousseau, O. S.; J. P. Brillard; B. Marquant-le Guienne; B. Guerin, A. Camus and $M$. Lechat (1998). Comparison of bacteriological qualities of various egg yolk sources and the in vitro and in vivo fertilizing potential of bovine semen frozen in egg yolk or lecithin based diluents. Theriogenology., 50: 699-706.

Duncan, D.B. (1955). Multiple Range and Multiple F. Test Biometrics, 11: 1-42. 
El-Keraby, F. E.; K. T. Osman; H. B. Ganah and E. M. El-Siefy (2010). Soymilk-based extender for cryopreservation of bovine semen. J. Anim. And Poultry Prod., 1 (2): 61-69.

El-Keraby, F. E.; E. M. E. El-Siefy and A. M. A. Hussein (2013). Soybean milk-based extender for cryopreservation of Egyptian buffalo bulls semen. Proceeding of the $4^{\text {th }}$ scientific conference of Anim. Prod. Res. Inst., 27-32.

El-Sharawy, M. E.; I. S. El-Shamaa,; M. A. R. Ibrahim,; I. M. Abd El-Razek, and E. M. El-Siefy, (2012). Effect of low density lipoproteins in extender on freezability and fertility of Egyptian buffalo bull semen. Scientific papers, Animal science. Series D, vol. LVCD- ROM ISSN 2285-5769, ISSN-L 2285-5750.

El-Siefy, E. M. (2014). Effect of addition different levels of soybean milk to tris diluent on the freezability and fertility of Holstein bulls semen. Kafrelsheikh, Vet. Med. J. Vol. 12: 225- 243.

Gilab, J.; M. Rodriguez-Irazoqui; N. Lundeheim; L. Soderquist and H. Rodriguez-Martinez (2003). Fertility of ram semen frozen in Bioexcell $B$ and used for cervical artificial insemination. Theriogenology., 59: 1157-1170.

Gil, J.; A. Januskausks; M. C. Haard; M. G. M. Haard; A. Johanisson; L. Soderquist and H. Rodriguez-Martinez (2000). Functional sperm parameters and fertility of bull semen extended in Biociphos Plus. Reprod. Domest. Anim., 35: 69-77.

Gil, J.; M. Rodriguez-Irazoqui; L. Soderquist and H. Rodriguez-Martinez (2002). Influence of centrifugation or low extension rates prefreezing on the fertility of ram semen after cervical insemination. Theriogenology, 57: 1781-1792.

Gil, J.; M. Rodriguez-Irazoqui; M., Lundeheim, N., Söderquist, L. and H.Rodríguez-Martínez, (2003). Fertility of ram semen frozen in Bioexcell and used for cervical artificial insemination. Theriogenology. 59:1157- 1170.

Hancock, J. I. (1951). A staining technique for the study of temperature shock in semen. Nature, Lond., $167: 223$.

Jeyendran, R. S.; H. H. Van Der Ven; M. Perez-Pelaez; B. G. Crabo and L. J. D. Zaneveled (1984). Development of an assay to assess the functional integrity of the human sperm membrane and its relationship to other semen characteristics. J. Reprod. Fertil. 70: 219-228.

Kasimanickam, R.; V. Kasimanickam,; A. Tibracy, and K. Pelzer, (2011). Effect of semen extenders on sperm parameters of ram semen during liquid storage at $4^{\circ} \mathrm{C}$. Small Rum. Res., 99: 208-213.

Khalifa, E. I. and M. A. M. Abdel-Hafez, (2014). Effect of soybean lecithinbased semen extender on freezability and fertility of Rahmani ram spermatozoa. Egyptian Journal of Sheep \& Goat Sciences, Vol. 9 (1), April, 59- 66. 
Khan, R.U.; Rahman, Z.U.; Javed, I. and F. Muhammad, (2012). Effect of vitamins, probiotics and protein on semen traits in post-molt male broiler breeders. Anim. Rep. Sci., 135:85-90.

Leboeuf, B.; Restall, B. and S. Salamon, (2000). Production and storage of goat semen for artificial insemination. Anim. Reprod. Sci., 62: 113-41.

Manjunath, P.; V. Nauc; A. Bergeron and M. Menard (2002). Major proteins of bovine seminal plasma bind to the low-density lipoprotein fraction of hen's egg yolk. Biol. Reprod., 67: 1250-1258.

Melrose, D. R. and J. A. Laing, (1970). The characteristics of normal semen. Ed. By J. A. laing Bailliere tindall and cassel. London.

Moustacas, V. S.; F. G. Zaffalon; M. A. Lagares; A. M. Loaiza-Eccheverri; F. C. Varago; M. M. Neves; L. G. D. Heneine; R. P. Arruda and M. Henry (2011). Natural, but not lyophilized, low density lipoproteins were an acceptable alternative to egg yolk for cryopreservation of ram semen. Theriogenology, 75: 300307.

Moussa, M.; V. Matinet; A. Trimeche; D. Tain-turier and M. Anton (2002). Low density lipoproteins extracted from hen egg yolk by an easy method: cryoprotective effect on frozen-thawed bull semen. Theriogenology., 57; 695-706.

Raden, I. A. and L. Y. Tuty (2010). Developing of tris soy milk diluent for Friesian Holstein bull frozen semen. HAYATI J. of Bioscinces, 17: 91-94.

Reed, M.L.; P.C. Ezeh; A. Hamic; D.J. Thomson and C.L. Caperton (2009). Soy lecithin replace egg yolk for cryopreservation of human sperm without adversely affecting posthawed motility, morphology, sperm DNA integrity or sperm binding to hyaluronate. J. Fert. Ster., 92: 1787-1790.

Rehman, F. U.; , M. S. Qureshi and R.U. Khan, (2014). Effect of soybean based extenders on sperm parameters of Holstein- Friesian bull during liquid storage at $4^{\circ} \mathrm{C}$. Pakistan J. Zool., vol. 46(1), 185-189.

Roof, D.J., S. Bowley, L.L. Price and D.J. Matsas. (2012). Comparison of two

commercial extenders for cryopreservation of goat semen without sperm

washing. Theriogenology., 77: 412- 420

Salisbury, G. W.; N. L. Van Demark and J. R. Lodge (1978). Physiol. of Reprod. and Al of cattle. H. freeman and Comp. San Francisco. U.S.A.

Singh, A. K., V. K. Singh, B. M. Narwade, T. K. Mohanty, and S. K. Atreja, (2012). Comparative quality assessment of buffalo (Bubalus bubalis) semen chilled $\left(5^{\circ} \mathrm{C}\right)$ in egg yolk- and soya milk-based extenders. Reprod. Domest. Anim., 47(4): 596600. 
Steel, R. G. D.; J. H. Torrie, and D .A. Dieky, (1997). Principles and procedures of statistics. 3rd Ed. McGraw Hill Book Co. Inc., New York.

Stradaioli, G.; T. Noro; L. Sylla and M. Monaci (2007). Decrease in glutathione (GSH) content in bovine sperm after cryopreservation: comparison between two extenders. Anim. Reprod. Sci., 67: 1249-1255.

Thun, R.; M. Hurtato and F. Janett (2002). Comparison of Biociphos-Plus and Tris-Egg yolk extender for cryopreservation of bull semen. Theriogenology., 57: 1087-1094.

Van Wagtendonk-Leeuw A. M.; R. M. Haring; L. M. Kaal-Landsbergen and J. H. den Daas (2000). Fertility results using bovine semen cryopreserved with extenders based on egg yolk and soybean extract. Theriogenology., 54: 57-67.

Watson, P.F. (1975). Use of a Giemsa stain to detect changes in acrosomes of frozen ram spermatozoa. Vet. Res., 97: 12-15.

Yotov, S. (2015). Effect of TFC-based extenders with soybean lecithin and/or low concentration of glycerol on the quality of goat chilled-stored semen. Int. Curr. Microbiol. App. Sci., 4(3): 752-761.

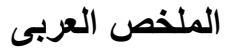

كفاءة استخدام مخفف لبن فول الصويا على تجميد الحوانات المنوية لذكور الماعز المباعل

وليد محمد سلطان*، الثناوى محمد الصيفى*، ابراهيم محمد عبد الرانق**، ابراهيم سعد

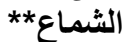

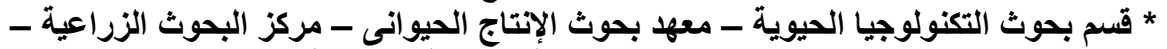

مصر. ** قسم الإنتاج الحيوانى ـ كلية الزراعة الزئة - جامعة كفر الشيخ

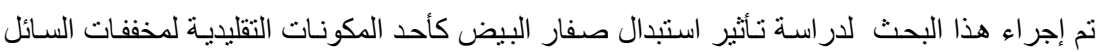

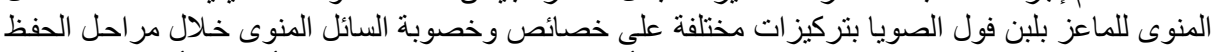

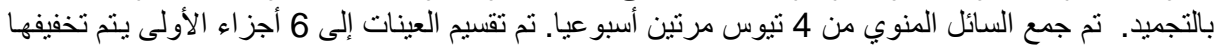

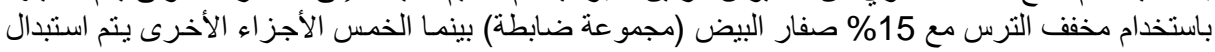

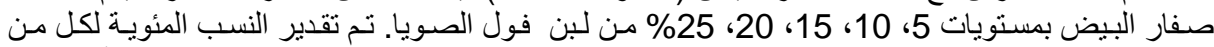

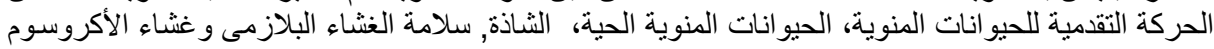

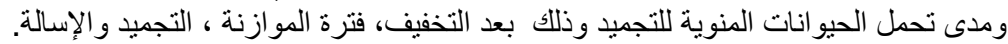

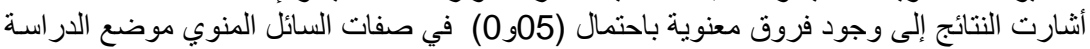

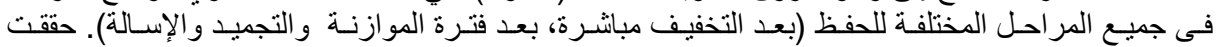

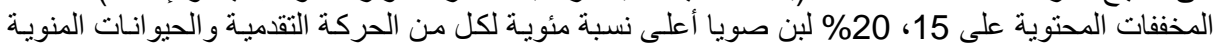

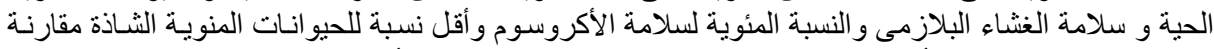

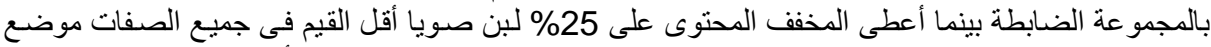

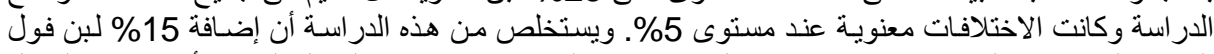

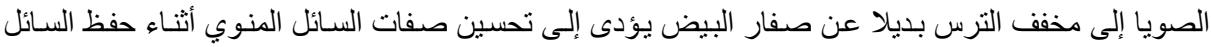
المنوى لذكور الماعز بالتجميد. التنبؤ بزيادة نسب الإخصاب بليض بالسائل المنوى المحفوظ بالتجميذ.
} 